2. Соціальна та кримінально-правова характеристика булінгу. Науковий вісник Херсонського державного університету. 2018. Вип. 3. Том 2. С. 107-110.

3. Що таке «булінг» та чому про нього треба знати всім батькам: пояснюють у центрі соціальних служб. URL: https://bilyayivka.city/ $\mathrm{read} /$ card/3080/scho-take-buling-ta-chomu-pro-nogo-treba-znati-vsim-batkampoyasnyuyut-u-centri-socialnih-sluzhb (дата звернення: 28.07.2019).

4. Кримінальний кодекс України: Кодекс України, Кодекс, Закон від 05.04.2001 № 2341-III. Відомості Верховної Ради Украӥни (ВВР). 2001. № 25-26. Ст. 131.

DOI https://doi.org/10.30525/978-9934-26-074-2-48

\title{
ПИТАННЯ КРИМІНАЛІЗАЦІЇ ПОРУШЕННЯ САНІТАРНИХ ПРАВИЛ І НОРМ ЩОДО ЗАПОБІГАННЯ ІНФЕКЦІЙНИМ ХВОРОБАМ В УМОВАХ ПАНДЕМІЇ COVID-19
}

\author{
Козерацька О. С. \\ старший викладач кафедри кримінального права, \\ кримінального прочесу та криміналістики \\ Одеського національного університету імені I. I. Мечникова \\ м. Одеса, Україна
}

Стрімке поширення світом гострої респіраторної хвороби COVID-19, спричиненої коронавірусом SARS-CoV-2 (далі - пандемія COVID-19), призвело до величезних економічних і людських втрат, що спонукало держави вжити радикальних заходів щодо захисту громадського здоров'я. Масштаби розповсюдження і ступінь тяжкості пандемії COVID-19 досягли такого рівня, коли, з точки зору охорони громадського здоров'я, деякі держави були вимушені ввести режим надзвичайного стану, як це передбачено національними конституційними нормами та відповідними Законами.

Урядами багатьох країн світу, 3 метою запобігання поширенню коронавірусної інфекції COVID-19, встановлено жорсткий карантин та запроваджено обмежувальні протиепідемічні заходи. Соціальне дистанціювання, режим самоізоляції, що представляють собою основну захисну міру по боротьбі з вірусом, та інші карантинні заходи, які були введені для стримування пандемії COVID-19, суттєво вплинули на світову економіку. Закриття магазинів, ресторанів і підприємств, що не 
відносяться до категорії життєво важливих, призвело до безпрецедентно високого рівня безробіття і до різкого зниження доходів населення. Ці обмежувальні заходи викликали соціальну напруженість в суспільстві, несанкціоновані протести, порушення правил карантину та самоізоляції, правовий нігілізм з боку певних верст населення, що ставить під загрозу зусилля урядів, спрямовані на захист населення і боротьбу з пандемією.

Останні дані свідчать про те, що в багатьох країнах світу як і раніше спостерігається щоденний приріст числа нових випадків COVID-19. Деякі країни в тій чи іншій мірі розширили або знову ввели ряд жорстких обмежень на пересування i контакти. Третя хвиля коронавірусної інфекції, що послідувала за ослабленням обмежень, мутації вихідного вірусу SARS-CoV-2, які є більш заразними і швидше поширюються на регіональному рівні, а існуючі вакцини дають менш ефективний захист від них, створили додаткову невизначеність щодо ходу розвитку і тривалості пандемії COVID-19. Отже, очевидно, що попередження поширення гострої респіраторної хвороби COVID-19, має підкріплюватися жорсткими державно-владними заходами, серед яких особливе значення мають кримінально-правові засоби протидії поширенню цього небезпечного інфекційного захворювання. До числа таких засобів відносяться норми кримінального закону про порушення санітарних правил і норм щодо запобігання інфекційним хворобам, зокрема, розповсюдженню гострої респіраторної хвороби COVID-19, недотримання правил карантину та самоізоляції. Крім того, у зв'язку із загрозою розповсюдження коронавірусної інфекції COVID-19, за певних обставин можливе вчинення інших правопорушень у період карантину, а саме: незаконне поширення конфіденційної інформації; грубе порушення громадського порядку під час здійснення евакуації громадян та забезпечення їм умов обсервації; дії, пов'язанні 3 нанесенням тілесних ушкоджень іншим особам; дії пов'язанні з завданням шкоди майну.

Криміналізація поширення коронавірусної інфекції COVID-19 має під собою досить міцне соціально-правове обгрунтування. Основним чинником, що свідчить про доцільність кримінально-правової протидії поширенню цього небезпечного інфекційного захворювання людини, виступає висока (кримінальна) ступінь суспільної небезпеки даного діяння, багато в чому обумовлена несприятливими тенденціями стрімкого збільшення кількості нових захворювань та летальних випадків унаслідок коронавірусної хвороби, а також довгостроковими наслідками після інфікування SARS-CoV-2 (біль у м'язах, втома та різноманітні психічні розлади, як-то страх та депресія). Підвищена суспільна небезпека масового поширення коронавірусної інфекції COVID-19 пов'язана ще і з тим, що національні системи охорони здоров'я були не 
готові до боротьби 3 цією інфекційною хворобою, відсутністю дієвих противірусних препаратів та засобів індивідуального захисту, браком коштів на реалізацію відповідних медико-санітарних, протиепідемічних заходів тощо.

За час пандемії у багатьох країнах Європи і світу періодично виникали масові несанкціоновані протести, як реакція на рішення влади про чергове посилення карантинних заходів, які швидко переростали в зіткнення $з$ поліцією. Особливе занепокоєння викликає той факт, що спочатку ці акції громадської непокори носили спонтанний характер, але 3 часом це перетворилося в «антикарантинний рух» у якому сплелися різні конспірологічні теорії, ковід-дисидентство, антивакцинаторські настрої та активність радикальних груп, переважно ультраправого спрямування. Отже, масштаб поширеності цих кримінально-протиправних діянь, значимість охоронюваних кримінальним законом цінностей, на які вони зазіхають, переважання позитивних наслідків криміналізації над негативними - $\epsilon$ вагомою підставою для криміналізації поширення коронавірусної інфекції COVID-19.

Кримінальне законодавство держав-членів Європейського союзу та інших держав світу про відповідальність за поширення небезпечних інфекційних захворювань людини, зокрема коронавірусної інфекції COVID-19, характеризується різноманіттям підходів до вирішення даної проблеми. При цьому в числі особливостей слід позначити такі аспекти: розширена диференціація кримінальної відповідальності за зараження інфекційною хворобою в залежності від форми і виду вини; встановлення кримінальної відповідальності за порушення санітарних правил i норм щодо запобігання інфекційним хворобам як за створення загрози, так і за фактичне поширення небезпечного інфекційного захворювання; диференціація відповідальності за умисне і необережне поширення небезпечного інфекційного захворювання; наявність у кримінальних кодексах прямих кримінально-правових заборон на поширення небезпечних інфекційних захворювань; суттєве посилення кримінальноправової репресії за порушення карантинних вимог та розповсюдження неправдивої інформації щодо пандемії COVID-19 (Кримінальні кодекси Республіки Польща, Чеської Республіки, Республіки Молдова, Закон про кримінальне право Ізраїлю) $[1$, ст. $165 ; 2$, ст.ст. 152,$153 ; 3$, ст. 215 ; 4, ст.ст. 218, 287].

Крім кримінальних кодексів у багатьох країнах світу діють акти змішаного кримінально-епідемічного законодавства, не кажучи вже про те, що існує інститут кримінальної відповідальності за вчинення кримінально-караних деліктів поряд з відповідальністю за адміністративні правопорушення, вчинені в період дії карантинних заходів, 
встановлених з метою запобігання поширенню інфекційних хвороб. Так, наприклад, правовою основою для введення на всій території Федеративної Республіки Німеччини жорстких і беззастережних обмежень через карантин, пов'язаний із загрозою подальшого поширення коронавіруса COVID-19, є федеральний «Закон про захист від інфекцій» (Infektionsschutzgesetz, IfSG). Зокрема, в параграфах $§ 73$ i $\S 74$ IfSG відображені види порушень, за які передбачено покарання у вигляді штрафів і позбавлення волі: максимально до 25.000 євро і до 5 років ув'язнення, відповідно [5, § 73 і § 74 ].

Застосування кримінального законодавства для регулювання поведінки людей та профілактики розповсюдження епідемічних та інших інфекційних хвороб - жорсткий i, 3 певної точки зору, радикальний підхід до того, щоб стримати розвиток пандемії COVID-19. Однак, зловживання санкціями кримінального законодавства нерідко має серйозні негативні наслідки і для конкретної людини, і для відповідних дій, і не враховує реалії життя людей. Використання кримінального законодавства може погіршити стигматизацію людей 3 вірусом, а страх стигматизації відштовхне інших людей від проходження тестування, i все це, в результаті, призведе до руйнування довіри між державою та суспільством. У надзвичайних ситуаціях, що загрожують здоров'ю населення, кримінальні закони часто тлумачаться розширено і розпливчасто, а їх застосування ризикує бути довільним і дискримінаційним. Але це зовсім не виключає необхідності криміналізації таких суспільно небезпечних діянь як порушення санітарних правил і норм щодо запобігання інфекційним хворобам, зокрема гострої респіраторної хвороби COVID-19. Кримінальне право в силу свого призначення не може ігнорувати нові форми деструктивної соціальної активності. I якщо локалізувати їх без використання кримінальної репресії неможливо, то при дотриманні всіх вимог до криміналізації діянь включення в кримінальні кодекси нових кримінально-правових заборон буде, безумовно, виправданим.

\section{Література:}

1. Кримінальний кодекс Республіки Польща. URL: http:// isap.sejm.gov.pl/isap.nsf/download.xsp/WDU20180001600/U/D20181600Lj.p df (дата звернення: 18.04.2021).

2. Кримінальний кодекс Чеської Республіки. URL: https:// www.epravo.cz/top/zakony/sbirka-zakonu/zakon-ze-dne-8-ledna-2009-trestnizakonik-17001.html (дата звернення: 18.04.2021). 
3. Кримінальний кодекс Республіки Молдова. URL: http://continent-online.com/Document/?doc_id=30394923\#pos=2637;38 (дата звернення: 18.04.2021).

4. Закон про кримінальне право Ізраїлю. URL: http://library.khpg.org/ files/docs/1375279180.pdf (дата звернення: 18.04.2021).

5. Федеральний «Закон про захист від інфекцій» (Infektionsschutzgesetz, IfSG). URL: https://www.gesetze-im-internet.de/ifsg/ (дата звернення: 18.04.2021).

DOI https://doi.org/10.30525/978-9934-26-074-2-49

\title{
БЕЗПРЕДИКАТНЕ РОЗСЛІДУВАННЯ ЛЕГАЛІЗАЦІЇ: МІФ ЧИ РЕАЛЬНІСТЬ ДЛЯ УКРАЇНИ
}

\author{
Красноборов О. В. \\ кандидат юридичних наук, \\ доцент кафедри кримінального та адміністративного права \\ Академії адвокатури України, \\ адвокат \\ м. Київ, Украӥна
}

Імплементація в національне кримінальне законодавство норм конвенцій Ради Свропи про відмивання, пошук, арешт та конфіскацію доходів, одержаних злочинним шляхом, повинна мати неабияке превентивне значення у боротьбі не тільки з легалізацією (відмиванням) майна, а й з іншими тяжкими злочинами, кінцевою метою яких є можливість інвестування здобутих злочинним шляхом доходів у реальний сектор економіки та подальше безперешкодне володіння і розпорядження набутими таким чином активами.

Утім, каменем спотикання на шляху до приведення нормативноправової бази України до європейських стандартів досі залишається питання запровадження механізму так званого безпредикатного розслідування легалізації (відмивання) майна, одержаного злочинним шляхом, що безумовно значно спрощує процес доведення вини особи у вчиненні цього злочину.

Водночас, щоб зрозуміти готовність нашої держави до практичної реалізації вказаного механізму, необхідно визначитися зі змістовним наповненням самого поняття «безпредикатність», що дедалі частіше вживається при розслідуванні злочинів указаної категорії. Чи це повне звільнення сторони обвинувачення від необхідності доведення 